\title{
Characteristics and Origins of Hot Springs in the Tatun Volcano Group in Northern Taiwan
}

\author{
Chia-Mei Liu ${ }^{1}$, Sheng-Rong Song ${ }^{1, *}$, Yaw-Lin Chen $^{1}$, and Shuhjong Tsao ${ }^{2}$ \\ ${ }^{1}$ Institute of Geosciences, National Taiwan University, Taipei, Taiwan, ROC \\ ${ }^{2}$ Central Geological Survey, Ministry of Economic Affairs, Taipei, Taiwan, ROC
}

Received 12 November 2010, accepted 25 May 2011

\begin{abstract}
This paper systematically surveyed distribution and field occurrences of 13 hot springs as well as geochemical investigation on the geothermal area of the Tatun Volcano Group (TVG). According to Piper diagrams, $\mathrm{pH}$ values, field occurrences and water-rock interactions, these hot springs can be classified into three types: (1) Type $\mathrm{I}, \mathrm{SO}_{4}^{2-}$ acidic water where the reservoir is located in the Wuchishan Formation; (2) Type II, $\mathrm{HCO}_{3}{ }^{-}$a near neutral spring where waters originate from the volcanic terrane (andesite); and (3) Type III, $\mathrm{Cl}^{-}$-rich acidic water where waters emanate from shallower Wuchishan Formation. In terms of isotopic ratio, $\delta \mathrm{D}$ and $\delta^{18} \mathrm{O}$ values, two groups of hot spring can be recognized. One is far away from the meteoric water line of the Tatun area with values ranging between $-26.2 \%$ and $-3.5 \%$, and from $-3.2 \%$ to $1.6 \%$, respectively. However, another close to the meteoric water line of the Tatun area is between $-28.4 \%$ and $-13.6 \%$, and from $-5.5 \%$ to $-4.2 \%$, respectively. In addition, the $\delta^{34} \mathrm{~S}$ value of thermal waters can also be distinguished into two groups, one ranging from $26.1 \%$ to $28.5 \%$, and the other between $0.8 \%$ and $7.8 \%$. Based on field occurrences and geochemical characteristics, a model has been proposed to illustrate the origin of these hot springs.
\end{abstract}

Key words: Taiwan, Tatun Volcano Group, Hot springs, Sulfur isotope, Stable isotope

Citation: Liu, C. M., S. R. Song, Y. L. Chen, and S. Tsao, 2011: Characteristics and origins of hot springs in the Tatun Volcano Group in northern Taiwan. Terr. Atmos. Ocean. Sci., 22, 475-489, doi: 10.3319/TAO.2011.05.25.01(TT)

\section{INTRODUCTION}

The variation of geochemical components of hot springs associated with volcanic activity is considered to be an important index (Giggenbach and Glover 1975; Williams et al. 1986; Martin-Del Pozzo et al. 2002; Cinzia et al. 2004; López et al. 2006). The characteristics of volcano-related hot springs can help to understand the processes of the volcanic degassing and the reservoir (McNutt and Beavan 1981; Rydelek et al. 1988; Neuberg 2000; Williams-Jones et al. 2001).

The Tatun Volcano Group (TVG) is located on the northern border of the Taipei Basin in northern Taiwan which includes a metropolitan area of more than seven million inhabitants. Two nuclear power plants are located only a few kilometers north and northeast of the TVG. The volcanoes of the TVG have usually been considered dormant or

\footnotetext{
* Corresponding author

E-mail: srsong@ntu.edu.tw
}

extinct because no historical eruptions have been recorded. However, a large number of shallow micro-earthquakes, harmonic codas and seismic tremors have been identified showing that a magma chamber may still exist beneath the TVG (Lin et al. 2005; Konstantinou et al. 2007). High heat flows with geothermal gradients higher than $100^{\circ} \mathrm{C} \mathrm{km}^{-1}$ were detected through geothermal exploration between 1960s and 1970s (MRSO 1969, 1970, 1971, 1973). Meanwhile, recent measurements of volcanic gases and ${ }^{3} \mathrm{He} /{ }^{4} \mathrm{He}$ ratios also show that an active magma chamber might still exist underneath the TVG (Yang et al. 1999; Lee et al. 2005, 2008; Lan et al. 2007). The TVG, thus, is recognized as "an active volcano" in Taiwan based on numerous micro-earthquakes, high heat flow and abnormally high helium ratios (Song et al. 2000a). Meanwhile, the youngest eruption was suggested to be ca. 6000 year ago based on recent study of the stratigraphy, volcaniclastic deposits, radiocarbon age, as well as the morphology of lava flows and domes in the TVG (Belousov et al. 2010). 
Since the 1960s, the hydrothermal systems of the TVG area, i.e., fumaroles, solfataras and hot springs with temperatures higher than $100^{\circ} \mathrm{C}$, have been found to be widely distributed in a belt $18 \mathrm{~km}$ long and $3 \mathrm{~km}$ wide from the Beitou to Chinshan areas (Fig. 1) and located predominantly along the surface trace of the Chinshan Fault (MRSO 1969). Those features show that the TVG exhibits strong post-volcanic activity. Hot springs for bathing and partial hydrotherapy have been well known since the $19^{\text {th }}$ century in the TVG, especially in the Beitou area. Several geochemical characteristics have been reported previously in the TVG, such as $\mathrm{SO}_{4}^{2-}$-rich acidity, near neutral $\mathrm{HCO}_{3}^{-}, \mathrm{Cl}^{-}$ rich acidity (MRSO 1969), and highly radioactive springs which occurred the Hokutolite (Okamoto 1918). Although some papers have described these hot springs based on the results of geothermal explorations conducted in the 1960s and 1970s (MRSO 1969, 1970, 1971, 1973), there has been no systematic research on the geochemical characteristics and origins of these hot springs. The temperature and $\mathrm{pH}$ value of hot springs of previous studies were from $30^{\circ} \mathrm{C}$ to $97^{\circ} \mathrm{C}$, between 1.25 and 7.6 , respectively.

In this study, we systematically surveyed the distribution and field occurrences of hot springs and sampled water from them for geochemical investigations in the geothermal areas of the TVG. The aim is to study the origins and processes in volcanic degassing and reservoir in different types of hot springs. Therefore, it will provide basic data to evaluate these hot springs as candidate sites for future monitoring of volcanic activity in the TVG.

\section{GEOLOGICAL BACKGROUND}

During the late Cenozoic, the island of Taiwan was created when the Philippine Sea plate obliquely collided with the Eurasian plate (Fig. 1). The island is located between two subduction zones (Ho 1986). In northern Taiwan, the Philippine Sea plate subducts northward under the Eurasian plate, producing the Ryukyu Island Arc system (Tsai 1978; Wu 1978; Suppe 1984; Teng 1996); in southern Taiwan, the South China Sea plate subducts eastward under the Philippine Sea plate, forming the Manila trench and the Luzon Arc system, where the Philippine Sea plate over-thrusts westward on the Eurasian continental margin (Seno 1977; Taylor and Hayes 1980). Presently, the Philippine Sea plate moves WNW with the rate ca. $80 \mathrm{~mm} \mathrm{yr}^{-1}$, and mountain-building processes are considered still ongoing (Yu et al. 1997).

Quaternary volcanoes in northern Taiwan consist of the Tatun and Chilung Volcano Groups, the Kuanyinshan Volcano and offshore volcanic islets, i.e., Chilungtao, Huapaingshu, Meinhuahsu, and Penghiahsu. These compositions of volcanic rocks are predominantly composed of andesite with a little basalt or dacite (Juang and Chen 1989; Song et al. 2000b; Lai et al. 2010; Tsai et al. 2010). Tectonically, they are spatially associated with the Ryukyu Island Arc (Chen 1975; Yen 1978), where the Philippine Sea plate subducts northward under the Eurasian plate (Tsai et al. 1981; Suppe 1984). Although related orogenic movement has occurred since $10 \mathrm{Ma}$, volcanism in northern Taiwan may be due to the MNW movement and westerly encroachment of

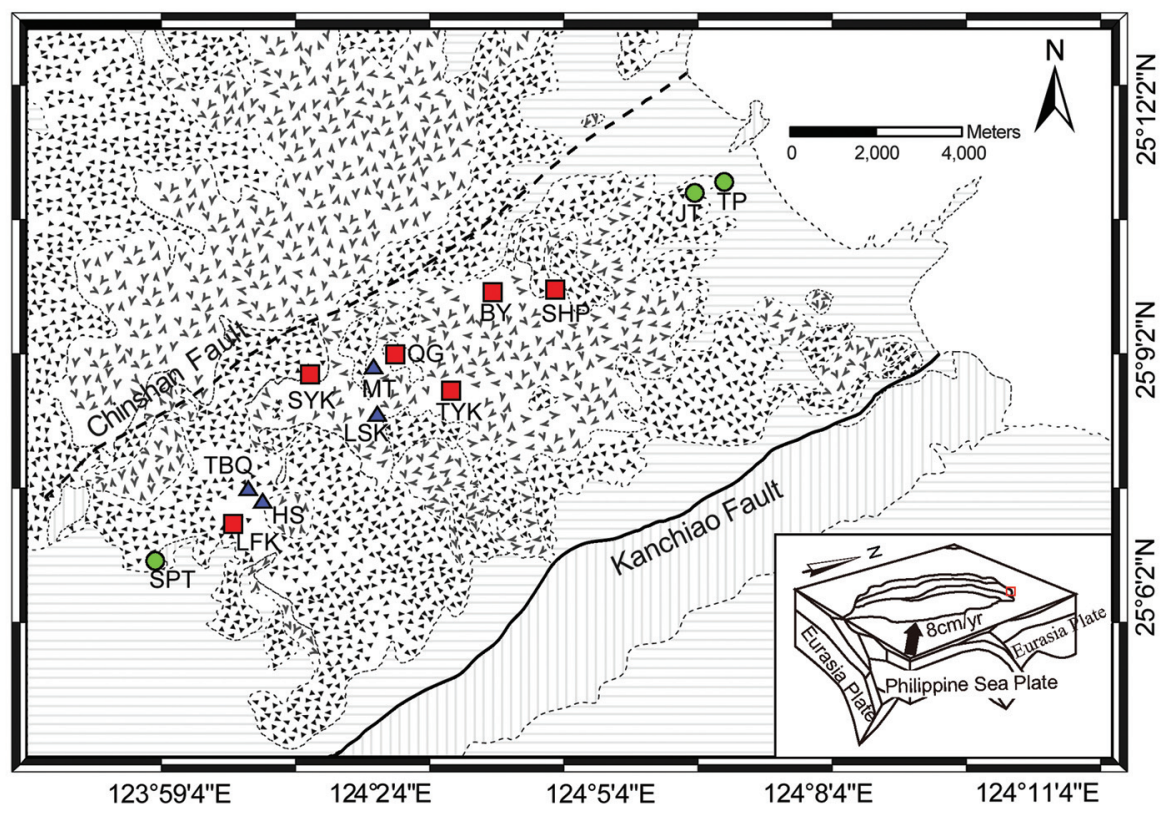

Legend

Mushan Formation \& the other Miocene Formations

W.... Wuchishan Formation

Andesitic lava

Andesitic breccia

Fig. 1. Schematic geological map showing the 13-sample-site locations in the Tatun geothermal area (modified from Huang 1998). There are three different types thermal water which are Type I thermal water (a red solid square), Type II hot spring (blue solid delta) and Type III thermal water (green solid circle). In the bottom right corner, it shows the Philippine Sea plate moves toward WNW with the rate of $80 \mathrm{~mm}^{\mathrm{r}} \mathrm{r}^{-1}$ and the red open square indicates this study area. 
the subducting Philippine Sea plate in the collision (Teng et al. 1992; Teng 1996). However, the magmatism in northern Taiwan might be related to post-collision collapse of a mountain belt rather than arc volcanism in terms of geochemical data (Wang et al. 1999, 2002, 2004).

The TVG, a typical multivent volcano, containing at least twenty volcanic composites, cones and domes in an area of $20 \times 20 \mathrm{~km}^{2}\left(400 \mathrm{~km}^{2}\right)$, occupies most volcanic areas in northern Taiwan (Chen and Wu 1971; Song et al. 2000b; Lai et al. 2010; Tsai et al. 2010). Volcanic bodies of the TVG, except for the Nantzeshan, Tinghouhsiushan, and Patotzeshan volcanoes, are mainly distributed along the Chinshan Fault with an east-northeast to northeast trend. They intersect at the Tatunshan volcano, forming a half amphitheater with a mouth opening to the north-northeast. The distributions and landforms of the volcanoes may have been formed by eruptions after lava domes and lava flows (Belousov et al. 2010).

Late Tertiary sedimentary sequences, i.e., the Wuchishan and Mushan Formations, occur as basement rocks below the volcanic body of the TVG. In addition, the volcanic rocks are predominantly composed of lava flows with subsidiary pyroclastic breccias, tuffs, lahars and reworked volcaniclastics. The TVG shows explosive activity from primary pyroclastic deposits that indicate eruptions of the TVG were less explosive than eruptions of subduction-related volcanoes in general (Belousov et al. 2010). The post volcanic activities of the TVG, i.e., hot springs and gas fumaroles, are well developed now and are mainly distributed in the periphery of main volcanic composites and cones along the Chihshan Fault with an area $18 \times 3 \mathrm{~km}^{2}$ from the south to the north of the TVG area (MRSO 1969, 1970, 1971, 1973; Chen and Wu 1971) (Fig. 1).

Based on dating results, the volcanic activities of the TVG can be divided into two major periods. The first period began ca. 2.8 - 2.5 Ma, and the second period was from 0.8 to 0.2 Ma (Juang and Chen 1989; Wang and Chen 1990; Juang 1993; Tsao 1994). Consequently, the TVG was identified as an extinct volcano group due to a lack of historically documented eruptions. However, recent study shows that the youngest volcano has significant magmatic eruptions at about $13000 \mathrm{BP}$ (and possibly 6000BP) in Mt. Chising (Belousov et al. 2010). Meantime, post volcanic activity, such as wide distribution fumaroles, solfatara and hot springs, helium isotopic data, and core records indicate that a magma chamber may exist underneath the TVG. The TVG, therefore, might still be an active volcano as defined by Szakács (Szakács 1994; Yang et al. 1999; Song et al. 2000a; Lin et al. 2005).

\section{FIELD OBSERVATION}

The host rocks of 13 hot-spring outcrops in the TVG area are divided into two groups. One group is located in volcanic terrane and the other is in sedimentary formations. The former includes ten hot springs, which are the Longfengku (LFK), Tingbiqiao (TBQ), Hoshan (HS), Lengshueiken (LSK), Hsiaoyukeng (SYK), Matsao (MT), Qigu (QG), Tayukeng (TYK), Bayan (BY), and Szehuangtzeping (SHP). The later contains three hot springs, which are Hsinpeitou (SPT), Jiatou (JT), and Tapu (TP).

The LFK, SYK, QG, TYK, BY, and SHP thermal water are located in andesitic breccias or lava flows, and they are associated with strong degassing of fumaroles. The country rocks of these samples have been altered by hydrothermal fluids with temperature and $\mathrm{pH}$ values varying between $42.8^{\circ} \mathrm{C}$ and $93.0^{\circ} \mathrm{C}$, between 1.5 and 3.2 , respectively. The total dissolved solids (TDS) of these samples are in the interval 245 to $12900 \mathrm{mg} \mathrm{L}^{-1}$, and associate with high temperature and low $\mathrm{pH}$ values. Meanwhile, yellowish needles or dendritic sulfur crystals are directly precipitated from the fumaroles gases, and deposited around the rims of hot springs. On the other hand, four hot springs, the Tingbiqiao (TBQ), Hoshan (HS), Lengshniken (LSK) and Matsao (MT) have near neutral $\mathrm{pH}$ values, and are also situated on volcanic bodies. The host rocks of these four samples are fresh andesitic rock, and their temperature and $\mathrm{pH}$ values are between $40.6^{\circ} \mathrm{C}$ and $61.7^{\circ} \mathrm{C}$ and between 5.8 and 6.5 , respectively. The TDS of them are in the interval 957 to $1149 \mathrm{mg} \mathrm{L}^{-1}$, except for at MT, which is about $295 \mathrm{mg} \mathrm{L}^{-1}$.

In addition, three hot springs, Hsinpeitou (SPT), Jiatou (JT) and Tapu (TP), are located on the Oligocene-Miocene sedimentary rocks of the Wuchishan Formation. These springs are acidic with $\mathrm{pH}$ values ranging from 1.2 to 1.9. Their temperature and TDS are between $71.8^{\circ} \mathrm{C}$ to $90.8^{\circ} \mathrm{C}$, and 17400 to $19800 \mathrm{mg} \mathrm{L}^{-1}$, respectively.

\section{SAMPLING AND ANALYTICAL METHODS}

In this study, all collected samples were filtered through $0.45-\mu \mathrm{m}$ cellulose filters in the field and stored in high-density polyethylene (HDPE). However, for cation analysis, we not only filtered the sample but also added ultra pure $\mathrm{HNO}_{3}$ to prevent precipitation in the field. In the laboratory, Yttrium is added in these samples as the internal standard.

The anions and cations were measured using an ion chromatograph (IC, Type Met-Rohm) and an inductively coupled plasma-atomic emission spectrometer (ICP-AES, Type Jobin-Yvon ULTIMA2), respectively. The uncertainties were less than $3 \%$ for the former and less than $2 \%$ for the latter. We used Zn reduction (Friedman 1953; Coleman et al. 1982; Kendall and Coplen 1985) and the $\mathrm{CO}_{2}$ equilibrium method (Cohn and Urey 1938; Epstein and Mayeda 1953) to collect the hydrogen and carbon dioxide gases from these samples and analyzed them using the Finnigan Delta Plus-Mass Spectrometer of this department with precisions of about $0.1 \%$ o for the oxygen isotopes and $1 \%$ o for the hydrogen isotopes, respectively. In addition, the sample 
is acidified and then the dissolved sulfate is precipitated by adding $\mathrm{BaCl}_{2}$, as barium sulfate $\left(\mathrm{BaSO}_{4}\right)$ (Yanagisawa and Sakai 1983). The sulfur isotopic values of these samples were analyzed by the Nuclidesmass Spectrometer of the laboratory of Illinois State Geological Survey, and their analytical uncertainties were $0.3 \%$.

\section{CHEMICAL AND ISOTOPIC COMPOSITIONS OF HOT SPRINGS}

\subsection{Water Chemistry}

Seven major elements, i.e., the $\mathrm{Na}^{+}, \mathrm{K}^{+}, \mathrm{Mg}^{2+}, \mathrm{Ca}^{2+}$, $\mathrm{HCO}_{3}{ }^{-}, \mathrm{Cl}^{-}$, and $\mathrm{SO}_{4}{ }^{2-}$ ions of these samples in the TVG, were analyzed and shown in Table 1 and Fig. 2 (Piper 1944).

With regard to the major anions of all samples in the TVG, the concentrations of $\mathrm{SO}_{4}{ }^{2-}, \mathrm{HCO}_{3}{ }^{-}$and $\mathrm{Cl}^{-}$range from 113 to $9980 \mathrm{mg} \mathrm{L}^{-1}$, from 56.3 to $777 \mathrm{mg} \mathrm{L}^{-1}$, and from 9.2 to $3990 \mathrm{mg} \mathrm{L}^{-1}$, respectively. Among them, nine samples are rich in $\mathrm{SO}_{4}{ }^{2-}$ compositions with concentrations between 340 to $9980 \mathrm{mg} \mathrm{L}^{-1}$ and lower $\mathrm{pH}$ values varying from 1.2 to 3.2 . They are from the LFK, SYK, QG, TYK, BY, SHP, JT, TP, and SPT thermal water (Table 1). Furthermore, four samples from the TBQ, HS, LSK, and MT thermal water being rich in $\mathrm{HCO}_{3}^{-}$, a bicarbonate, have near neutral $\mathrm{pH}$ values ranging from 5.8 to 6.5 (Fig. 3). In addition, three samples from the SPT, JP, and TP thermal water are rich in chloride, with concentrations ranging from 830 to $3990 \mathrm{mg} \mathrm{L}^{-1}$.
Moreover, the major cations of all thermal water in the TVG are $\mathrm{Na}^{+}, \mathrm{K}^{+}, \mathrm{Mg}^{2+}$ and $\mathrm{Ca}^{2+}$ and they range from 5.5 to $1496 \mathrm{mg} \mathrm{L}^{-1}$, from 1.5 to $253 \mathrm{mg} \mathrm{L}^{-1}$, from 2.0 to $209 \mathrm{mg}$ $\mathrm{L}^{-1}$, and from 5.3 to $382 \mathrm{mg} \mathrm{L}^{-1}$, respectively. Three samples, the SPT, JT and TP thermal waters, are rich in $\mathrm{Na}^{+}$compositions with concentrations ranging from 410 to $1496 \mathrm{mg} \mathrm{L}^{-1}$ and the other samples, i.e., the LFK, TBQ, HS, LSK, SYK, MT, QG, TYK, BY, and SHP thermal waters, are lower in $\mathrm{Na}^{+}$compositions with concentrations between 5.5 and $97.0 \mathrm{mg} \mathrm{L}^{-1}$ (Table 1). Moreover, potassium concentrations of ten samples are less than $70.8 \mathrm{mg} \mathrm{L}^{-1}$. Furthermore, six samples are poor in $\mathrm{Mg}^{2+}$ concentrations ranging from 2.0 to $35.7 \mathrm{mg} \mathrm{L}^{-1}$. Finally, the calcium concentrations of seven samples, named the SPT, TBQ, HS, LSK, SYK, JT, and TP thermal waters, are enriched between 118 to $382 \mathrm{mg} \mathrm{L}^{-1}$.

\subsection{Isotopic Results}

\subsubsection{Hydrogen and Oxygen Isotopes}

In the TVG area, previous studies on the oxygen and hydrogen isotopic ratios of rain water and showed variations ranging from $-6.31 \%$ o to $-5.13 \%$ and from $-40.5 \%$ to $-16.3 \%$, respectively (Liu 1984). Furthermore, the meteoric water line was constructed, and the corresponding least square regression equation was given to be $\delta \mathrm{D}=(9.3 \pm$ 1.2) $\delta^{18} \mathrm{O}+(27 \pm 8)$ with a correlation coefficient of about

Table 1. Chemical and isotopic compositions $\left(\mathrm{mg} \mathrm{L}^{-1} ; \delta^{18} \mathrm{O}\right.$ and $\delta \mathrm{D}$ in $\% \mathrm{~V}-\mathrm{SMOW} ; \delta^{34} \mathrm{~S}$ in $\% \mathrm{CDT}$ ) of 13 hot-spring samples from the TVG (NA: not analyzed; -: below detection limit).

\begin{tabular}{|c|c|c|c|c|c|c|c|c|c|c|c|c|c|c|c|}
\hline Sample name & Date & Type & Temp. $\left({ }^{\circ} \mathrm{C}\right)$ & pH & TDS & $\mathrm{Na}^{+}$ & $\mathbf{K}^{+}$ & $\mathrm{Ca}^{2+}$ & $\mathbf{M g}^{2+}$ & $\mathrm{HCO}_{3}^{-}$ & $\mathrm{SO}_{4}{ }^{2-}$ & $\mathrm{Cl}^{-}$ & $\delta^{18} \mathrm{O}$ & $\delta \mathrm{D}$ & $\delta^{34} \mathrm{~S}$ \\
\hline SPT & $07 / 03 / 27$ & III & 71.8 & 1.3 & 17600 & 1017 & 216 & 151 & 81.2 & - & 2644 & 3152 & -3.2 & -26.2 & 26.1 \\
\hline LFK & $07 / 03 / 27$ & I & 80.3 & 3.2 & 600 & 16.7 & 5.9 & 51.6 & 14.4 & - & 448 & 24.7 & -3.1 & -24.8 & NA \\
\hline TBQ & $07 / 03 / 27$ & II & 47.5 & 6.5 & 957 & 73.1 & 20.0 & 154 & 65.6 & 317 & 281 & 81.1 & -5.1 & -28.4 & NA \\
\hline HS & $07 / 03 / 27$ & II & 41.4 & 6.5 & 1100 & 69.9 & 22.1 & 161 & 88.7 & 777 & 113 & 94.3 & -5.5 & -27.5 & NA \\
\hline LSK & $07 / 03 / 27$ & II & 40.6 & 6.1 & 1149 & 57.6 & 19.0 & 163 & 60.7 & 209 & 299 & 195 & -5.3 & -25.9 & 7.8 \\
\hline SYK & $07 / 03 / 27$ & I & 93.0 & 2.3 & 7900 & 97.0 & 18.2 & 382 & 85.7 & - & 1001 & 461 & 1.6 & -3.5 & 3.4 \\
\hline MT & $07 / 03 / 27$ & II & 61.7 & 5.8 & 295 & 15.5 & 4.8 & 48.3 & 13.5 & 56.3 & 201 & 9.2 & -4.3 & -21.0 & 0.8 \\
\hline QG & $07 / 03 / 27$ & I & 42.8 & 2.3 & 660 & 37.1 & 14.3 & 97.5 & 35.7 & - & 1009 & 358 & -4.6 & -21.2 & NA \\
\hline TYK & $07 / 03 / 27$ & I & 85.3 & 1.5 & 12900 & 19.1 & 70.8 & 28.8 & 12.6 & - & 9980 & 50.6 & -0.6 & -10.1 & NA \\
\hline BY & $07 / 03 / 27$ & I & 81.2 & 2.7 & 772 & 17.5 & 3.5 & 28.2 & 9.9 & - & 340 & 38.1 & -2.1 & -12.1 & NA \\
\hline SHP & $07 / 03 / 27$ & I & 77.6 & 3.2 & 245 & 5.5 & 1.5 & 5.3 & 2.0 & - & 346 & 20.3 & -4.2 & -13.6 & 3.3 \\
\hline JT & $07 / 03 / 27$ & III & 78.0 & 1.2 & 19800 & 410 & 133 & 118 & 102 & - & 574 & 830 & -2.4 & -12.1 & NA \\
\hline TP & $07 / 03 / 27$ & III & 90.8 & 1.9 & 17400 & 1496 & 253 & 185 & 209 & - & 998 & 3990 & -1.8 & -6.5 & 28.5 \\
\hline \multicolumn{3}{|c|}{$\begin{array}{c}\text { Brine water of the } \\
\text { Wuchishan Formation* }\end{array}$} & NA & NA. & NA & 5560 & 910 & 630 & 680 & NA & 115 & 14900 & NA & $\mathrm{NA}$ & NA \\
\hline
\end{tabular}

\footnotetext{
* The brine water is a reservoir of the Wuchishan Formation that is collected from the exploration well of the SPT (Chen 1989).
} 




Fig. 2. Piper diagram showing major element compositions of the 13 hot springs. Type I thermal water (red symbols), Type II hot spring (blue symbols) and Type III thermal water (green symbols).

0.9. The samples were collected between June 1982 and June 1983 (Liu 1984) (Fig. 4).

The hydrogen and oxygen isotopic data of the TVG thermal water are listed in Table 1 and plotted in Fig. 4. The isotopic ratios of all samples fall to the right of the meteoric water line of the Tatun area and can be divided into two groups. One group is far away from the local meteoric water line, that is, the SYK, TYK, TP, BY, JT, LFK, and SPT thermal water, the isotopic values of which range from $-26.2 \%$ to $-3.5 \%$ and $-3.2 \%$ to $1.6 \%$, respectively. The other is close to meteoric water line of the TVG, i.e., the SHP, MT, QG, TBQ, LSK, and HS thermal water, the $\delta D$ value of which range from $-28.4 \%$ to $-13.6 \%$, and $\delta^{18} \mathrm{O}$ from $-5.5 \%$ o to $-4.2 \%$, respectively.

\subsubsection{Sulfur Isotopes}

The sulfur isotopic compositions of some samples collected from hot springs were analyzed, and the results are listed in Table 1. The results are divided into two groups. One group ranges from $26.1 \%$ to $28.5 \%$, and these samples are from the TP and SPT thermal water. The other group ranges from $0.8 \%$ to $7.8 \%$, and they are from the LSK, MT, SHP and SYK thermal water.

\subsection{Classifications and Distributions of Hot Springs}

According to host rocks, $\mathrm{pH}$ values, and the major elements, the hot springs from the TVG can be classified into three types. They are the $\mathrm{SO}_{4}^{2-}$, and $\mathrm{Cl}^{-}$acidic thermal wa-

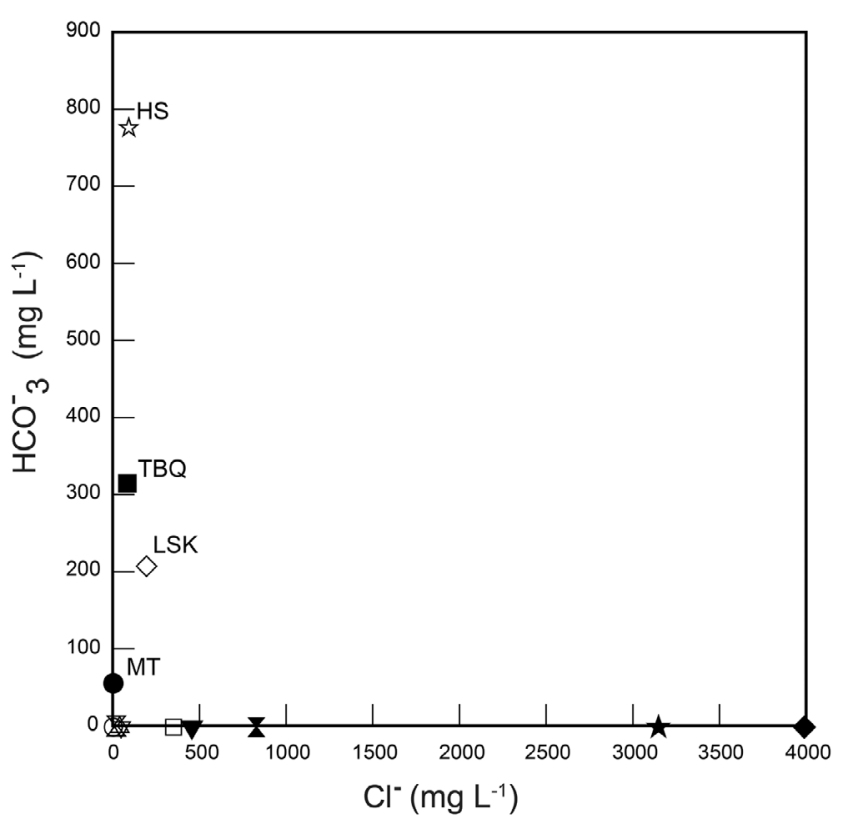

Fig. 3. Plots of $\mathrm{Cl}^{-}$versus $\mathrm{HCO}_{3}{ }^{-}$showing the $\mathrm{HS}$, TBQ, LSK and MT thermal water rich in concentrations of $\mathrm{HCO}_{3}^{-}$in the volcanic host body.

ter, and $\mathrm{HCO}_{3}^{-}$near neutral hot spring, as shown in Fig. 1. The geochemical characteristics of these three types are described in detail in following sections.

(1) The $\mathrm{SO}_{4}{ }^{2-}$ acidic thermal water, named Type $\mathrm{I}$, is characterized by the occurrence of yellowish dendritic sulfur crystals precipitated around the rims of fumaroles and 


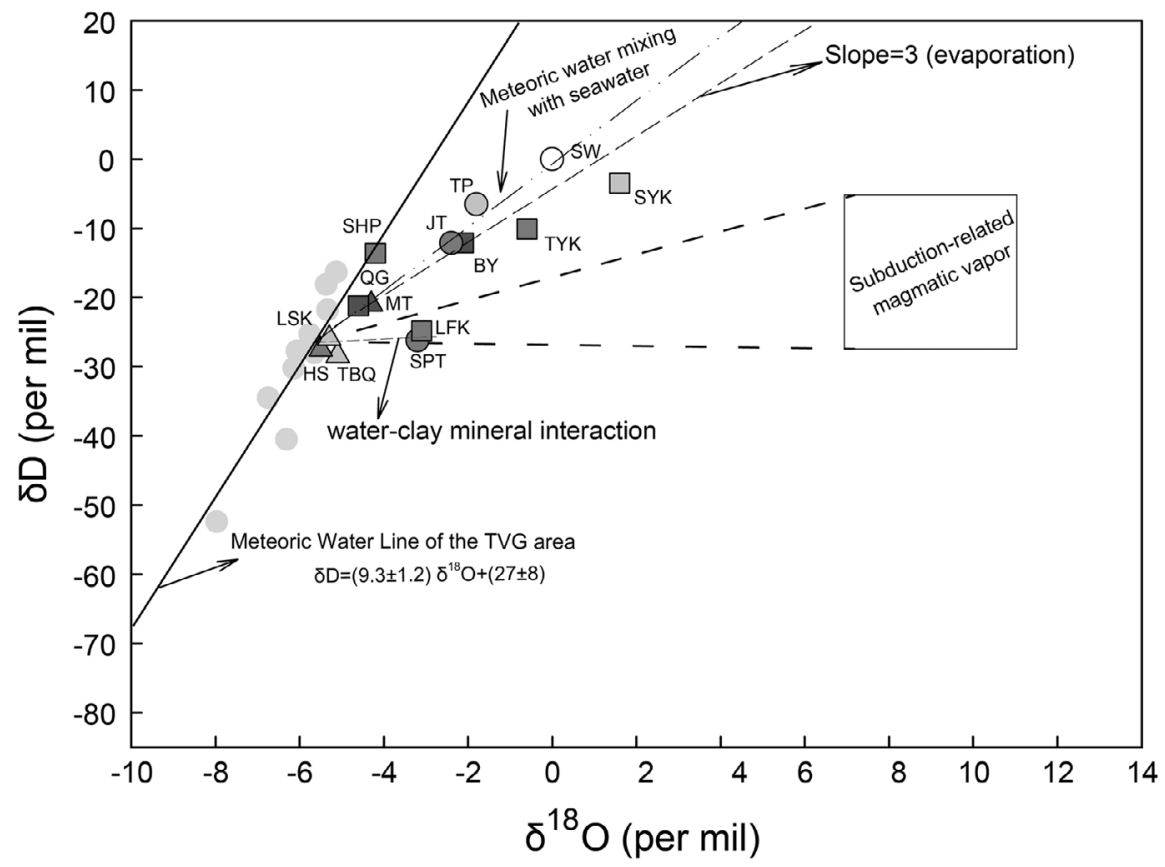

Fig. 4. Plots of $\delta \mathrm{D}$ versus $\delta^{18} \mathrm{O}$ diagram for thermal water in the TVG area. The stable isotopic ratio of the meteoric water of the Tatun (the gray circles) is from a previous study (Liu et al. 1984). All of the samples fall to the right of the meteoric water line in the Tatun area.

by strong degassing of volcanic gases. This thermal water is predominantly distributed around volcanic centers with host rocks consisting of andesitic breccias and/or lava flows. Hot springs of this type are the LFK, SYK, QG, TYK, BY, and SHP thermal water. In situ measurements of temperature, TDS, and $\mathrm{pH}$ are conducted and the values range from $42.8^{\circ} \mathrm{C}$ to $93.0^{\circ} \mathrm{C}, 245$ to 12900 $\mathrm{mg} \mathrm{L}^{-1}$, and 1.5 to 3.2 , respectively (Table 1 ). Geochemically, Type $\mathrm{I}$ is dominated by significantly higher $\mathrm{SO}_{4}{ }^{2-}$, and lower $\mathrm{HCO}_{3}{ }^{-}$and $\mathrm{Cl}^{-}$in anions, and lower $\mathrm{Na}^{+}, \mathrm{K}^{+}$, $\mathrm{Mg}^{2+}$ and $\mathrm{Ca}^{2+}$ concentrations in cations. Meanwhile, the ratio of hydrogen and oxygen range from $-24.8 \%$ to $-3.5 \%$ and $-4.6 \%$ o to $1.6 \%$, respectively (Fig. 4). Among all of the isotopic values of the samples in this group, the most are far away from the meteoric water line of the TVG, in particular, the SYK thermal water with hydrogen and oxygen isotopic ratio of $-3.5 \%$ and $1.6 \%$, respectively (Fig. 4). The sulfur isotopic value of this type varies from $3.3 \%$ to $3.4 \%$.

(2) The $\mathrm{HCO}_{3}{ }^{-}$near neutral hot spring (Type II) that thermal water is predominantly distributed in host rocks of fresh or less altered andesitic breccias and/or lava flows with weak degassing of volcanic gasses. Hot springs belonging to this type includes the TBQ, HS, LSK and MT thermal water. In situ measurements of $\mathrm{pH}$, temperature and TDS range from 5.8 to 6.5 , from $40.6^{\circ} \mathrm{C}$ to $61.7^{\circ} \mathrm{C}$, and from 295 to $1149 \mathrm{mg} \mathrm{L}^{-1}$, respectively (Table 1). The ratios of hydrogen and oxygen vary from $-28.4 \%$ to $-21.0 \%$ and from $-5.5 \%$ to $-4.3 \%$, respectively, and are close to the meteoric water line of the Tatun area (Fig. 4).
For the hot springs of this type, the sulfur isotopic value, $\delta^{34} \mathrm{~S}$ ranges from $0.8 \%$ to $7.8 \%$.

(3) The $\mathrm{Cl}^{-}$-rich acidic thermal water (Type III) includes the SPT, JT and TP thermal water. It is characterized by chloride rich and low $\mathrm{pH}$ values. It is located at the Wuchishan Formation of sedimentary terrane, which is predominantly composed of massive and large-grained quartz-rich sandstones. Field measurements show that the $\mathrm{pH}$ values are between 1.2 and 1.9. Moreover, temperature and TDS of this type range from $71.8^{\circ} \mathrm{C}$ to $90.8^{\circ} \mathrm{C}$, and from 17400 to $19800 \mathrm{mg} \mathrm{L}^{-1}$, respectively. In addition, the geochemical characteristics of this type show significantly higher concentration of $\mathrm{Na}^{+}$and $\mathrm{Cl}^{-}$, which is very similar to the seawater or formation water. Stable isotopic values of hydrogen and oxygen in the Type III thermal water are relatively far away from the meteoric water line of the Tatun area, being between $-26.2 \%$ and $-6.5 \%$ and between $-3.2 \%$ and $-1.8 \%$, respectively. Meanwhile, the hydrogen and oxygen stable isotopic ratio of the TP thermal water is close to seawater and higher than other samples of Type III thermal water. The sulfur isotopic value, $\delta^{34} \mathrm{~S}$, of this type ranges from $26.1 \%$ to $28.5 \%$.

\section{DISCUSSION}

\subsection{Source Components of Hot Springs}

In general, the source of thermal water or hot spring can be summarized as follows: meteoric water circulates to depth, is heated by magma or the normal geothermal gra- 
dient, then reacts with minerals or host rocks, magmatic fluids, formation water or seawater that may have changed composition in the reservoir, and is finally driven to the surface by thermal convection (Todd 1980; Henley and Ellis 1983; Giggenbach 1988; Nicholson 1993; Kühn 2004). Accordingly, several studies suggest that the possible source components involved in producing thermal water or hot spring include meteoric water, seawater/formation water, magmatic fluids, host rocks and clay minerals (Craig 1963; Ellis and Mahon 1964; Seyfried and Bischoff 1981).

In the TVG, a magmatic source provides the heat and fluid components for thermal water distinctly by the results of the abundant seismic tremors, harmonic codas and volcanic earthquakes, gas compositions, helium isotopic ratio, low $\delta^{34} \mathrm{~S}$ of volcanic gas, and high heat flows (Song et al. 2000a; Yang et al. 2003; Lin et al. 2007; Ohba et al. 2010). Moreover, the sulfur isotopic ratio $\left(\delta^{34} \mathrm{~S}\right)$ with values ranging from $0.8 \%$ to $7.8 \%$, which is indicative of a magmatic source (Criss 1999; Hoefs 2004; Ohba et al. 2010). These lines of evidence strongly infer that magmatic fluids play a major role for the origin of thermal water or hot spring in the TVG.

Generally, meteoric water always plays major role in providing fluids for thermal water or hot spring. Based on the plots of hydrogen and oxygen isotopic ratio (Fig. 4), samples of this study falling near the meteoric water line suggest that the water is predominantly from precipitation. In that case, meteoric water plays an important role in the provision of thermal water or hot spring in the TVG.

In addition, some thermal waters (SPT, JT and TP) have higher sulfur isotopic ratio $\left(\delta^{34} S\right)$ with values ranging from $26.1 \%$ to $28.5 \%$ and high concentrations of chloride $\left(\mathrm{Cl}^{-}\right)$and sodium $\left(\mathrm{Na}^{+}\right)$, which display characteristics of seawater or formation water (Table 1). They are distributed in the sedimentary terrane or near the coast. It infers that the seawater or formation water is also involved in the origin of thermal water or hot springs.

The host rocks, all of the thermal water of the TVG, are either volcanic body or sedimentary terrane, so hot springs may react with rocks or minerals to change the compositions of the fluid. The host rocks, therefore, also play a major role for the origin of thermal water or hot springs.

As we indicated in the aforementioned evidence, the possible source components of the TVG area involved in generating thermal water or hot spring include meteoric water, magmatic fluids, seawater/formation water which reacts with or is neutralized by either volcanic or sedimentary rocks.

\subsection{Origins of Hot Springs in the TVG}

\subsubsection{Origin of Type I Thermal Water}

Type $\mathrm{I}$ is $\mathrm{SO}_{4}{ }^{2-}$ acidic thermal water and occurs in hydrothermal volcanic host rocks. Two source components can be recognized, including meteoric water and magmatic fluids (Criss 1999; Hoefs 2004) for this type. The evidence of source of Type I is supported by an artificial hot spring, which is a famous bathing and partial hydrotherapy area in the Beitou. In the resort area of Beitou, it is a block square pool built on the outlet of fumaroles that allows the inflow of surface water into the pool after absorbing the volcanic gases to produce the hot spring. Its temperature, $\mathrm{pH}$ value, and geochemical compositions are similar with Type I thermal water, except for the lower values of $\mathrm{Cl}^{-}$and $\mathrm{HCO}_{3}$. These lines of evidence strongly supported that Type I water is predominantly produced by the mixing of magmatic fluids and meteoric water with little or no contribution from the host rocks.

The formation of high $\mathrm{SO}_{4}{ }^{2-}$ acidic thermal water likely occurs in the same process of artificial hot spring. The TVG is an active volcano group with significantly strong volcanic-gas activity and yellowish sulfur dendritic crystals precipitating around the rims of fumaroles or solfataras widely. The magmatic heat and fluids or gases migrating upward from depth to the groundwater system generate thermal waters and/or hot springs. In the TVG area, volcanic gases are predominantly composed of $\mathrm{H}_{2} \mathrm{~S}, \mathrm{SO}_{2}, \mathrm{CO}_{2}$ and $\mathrm{HCl}$ (Lee et al. 2005), and the $\mathrm{CO}_{2}$ of fumarolic gases of the TVG mainly originate from the upper mantle (Ohba et al. 2010). As a result, this type samples may originate from magmatic fluids mixing with meteoric water and circulating in the groundwater, and then exhibit higher $\mathrm{SO}_{4}{ }^{2-}$ concentration and show the characteristic of acidic thermal water $(\mathrm{pH} 1.5$ to 3.2). The reaction equations of water-gas interaction in the TVG are:

$\mathrm{H}_{2} \mathrm{~S}+4 \mathrm{H}_{2} \mathrm{O} \rightleftharpoons \mathrm{H}_{2} \mathrm{SO}_{4}+4 \mathrm{H}_{2}$

$\mathrm{SO}_{2}+2 \mathrm{H}_{2} \mathrm{O} \rightleftharpoons \mathrm{H}_{2} \mathrm{SO}_{4}+\mathrm{H}_{2}$

Furthermore, the volcanic rocks of the TVG have been organized to overlay on the Wuchishan Formation based on the field surveys and exploration wells (MRSO 1969). This sedimentary formation is composed predominantly of quartz grains with subsidiary feldspar, chert, lithic fragment, rhyolitic pebble and clay minerals (Chen 1963; Wu 1967) that do not have enough alkali contents to neutralize acidic thermal water. In addition, some economically viable clay mineral deposits, and brine/formation water with composition similar to seawater have been found in the Wuchishan Formation (Chen 1989).

The Type I thermal water maintains its acidic characteristics (low $\mathrm{pH}$ ) and high $\mathrm{SO}_{4}{ }^{2-}$, and also displays the magmatic source by the sulfur isotopic ratio $\left(\delta^{34} S\right)$. The sulfur isotopic value of volcanic gas, which is predominantly $\mathrm{H}_{2} \mathrm{~S}$, is between $-5.3 \%$ and $10.4 \%$ in the TVG area (Ohba et al. 2010). It implies that the water-rock interaction does not or 
very little occur to neutralize the thermal water in the reservoir of Type I. Meanwhile, the major elements of Type I are different from the brine/formation water of the Wuchishan Formation. It means that the reservoir may be close to the heat source and no or very little brine/formation water is involved in the generation of the thermal water. Those observations, therefore, suggest that the reservoir of Type I may be located in the deep of Wuchishan Formation.

Furthermore, plots on the hydrogen and oxygen stable isotopic diagram for Type I indicate that almost all the thermal waters do not fall in the meteoric water and magmatic fluids mixing area. They are close to the evaporation line, except for the Longfengku (LFK) (Fig. 4). Based on this characteristic, we infer that Type I is likely also affected by evaporation during its rise to the surface. It is supported by the positive correlation between $\delta^{18} \mathrm{O}$ vs. elevation, temperature, and chlorine (Craig 1963; Gat and Dansgaard 1972; Shieh et al. 1983; Gonfiantini 1986; Ohba et al. 2010) (Fig. 5). However, high chlorine concentration of the QG is associated with lower temperature than ones of the other springs of Type I. In addition, the Longfenku (LFK) is close to the Gueizikeng area, where clay minerals were mined previously. Therefore, the shift of stable isotopic ratio in LFK might be caused by water-clay mineral interaction, and the isotopic fractionation for water-clay mineral system caused the $\delta^{18} \mathrm{O}$ shift greater than the $\delta \mathrm{D}$ shift (Savin and Epstein 1970; Lawrence and Taylor 1972; James and Baker 1976; Criss 1999; Hoefs 2004) (Fig. 5).

In summary, this study infers that the origin of Type I thermal water involves three components, the meteoric water, magmatic fluids, and sedimentary rocks from the Wuchishan Formation with evaporation and/or water-clay minerals interaction. Accordingly, three stages can be identified for the origin of Type I thermal water. First, the meteoric water circulates into deep groundwater system, and then it is heated and reacts with uprising magmatic fluids or volcanic gases to produce acidic thermal water with low $\mathrm{pH}$, higher temperature and $\mathrm{SO}_{4}{ }^{2-}$ content, as well as positive stable isotopic values for hydrogen and oxygen. Subsequently, it is evident that the reservoir is located in the deep of Wuchishan Formation, a region that lacks suitable minerals to neutralize the thermal water, allowing its acidic nature to prevail during water-rock interaction. Finally, when the high temperature acidic thermal water rises from its deep reservoir to the surface by thermal convection, it is subject to evaporation by depressurization. However, the LFK thermal water with oxygen isotopic shift may be caused by waterclay mineral interaction.

\subsubsection{Origin of Type II Hot Spring}

Type II hot spring belongs to a $\mathrm{HCO}_{3}^{-}$neutral hot spring and occurs in volcanic host rocks. The fluid source components for generating this type are meteoric water and subduction-related magmatic fluids suggested by their geochemical characteristics (Criss 1999; Hoefs 2004).



Fig. 5. Evaporation process is a major factor that caused concentrations of chloride at the LFK, SYK, QG, TYK, BY, and SHP thermal water (Type I). 
It is important to note that the Type I and Type II hot springs exhibit similar fluid components with different host rocks. However, the Type II hot spring shows the characteristics of neutral $\mathrm{pH}$ and higher $\mathrm{HCO}_{3}{ }^{-}$values (Fig. 3) which is different from Type I. As mentioned in a previous section, the Wuchishan Formation is the basement rock of the TVG, and the mineral assemblages of the volcanic rock and the Wuchishan Formation are significantly different. In general, the volcanic rock is composed predominantly of twopyroxene and two-pyroxene hornblende andesites, possessing plagioclases as major phenocrysts, and the Wuchishan Formation is composed of course sandstone with abundant quartz grains (Chen 1963; Wu 1967). Previous studies have shown that the acidic thermal water could react with plagioclase to neutralize the water, reduce $\mathrm{SO}_{4}{ }^{2-}$ ion concentrations and generate anhydite, montmorillonite, kaolinite, calcite and alunite as hydrothermally precipitated minerals (Chen and Yang 1984; Liu et al. 1984; Wang 1991; Muir and Nesbitt 1992; Nogami and Yoshida 1995; Kempter and Rowe 2000; Varekamp et al. 2000; Fang et al. 2003; Marini et al. 2003).

The reaction equations can be written as:

$$
\begin{aligned}
& \mathrm{CaAl}_{2} \mathrm{Si}_{2} \mathrm{O}_{8}(\text { anorthite })+\mathrm{H}_{2} \mathrm{SO}_{4}+2 \mathrm{H}_{2} \mathrm{O} \rightleftharpoons \\
& \mathrm{CaSO}_{4}(\text { anhydrite })+\mathrm{Al}_{2} \mathrm{Si}_{2} \mathrm{O}_{5}(\mathrm{OH})_{4}(\text { kaolinite }) \\
& \left.\mathrm{CaAl}_{2} \mathrm{Si}_{2} \mathrm{O}_{8} \text { (anorthite }\right)+\mathrm{CO}_{2}+2 \mathrm{H}_{2} \mathrm{O}= \\
& \mathrm{CaCO}_{3}(\text { calcite })+\mathrm{Al}_{2} \mathrm{Si}_{2} \mathrm{O}_{5}(\mathrm{OH})_{4}(\text { kaolinite })
\end{aligned}
$$

$$
\begin{aligned}
& \mathrm{NaAlSi} \mathrm{O}_{8}(\text { albite })+\mathrm{H}_{2} \mathrm{CO}_{3}+4.5 \mathrm{H}_{2} \mathrm{O}= \\
& \quad 0.5 \mathrm{Al}_{2} \mathrm{Si}_{2} \mathrm{O}_{5}(\mathrm{OH})_{4}(\text { kaolinite })+\mathrm{Na}^{+}+\mathrm{HCO}_{3}^{-}+2 \mathrm{H}_{4} \mathrm{SiO}_{4}
\end{aligned}
$$

$$
\begin{gathered}
\text { Alunite + kaolinite }+10 \mathrm{SiO}_{2}+\mathrm{Mg}_{2}+\mathrm{H}_{2} \mathrm{O}= \\
3 \mathrm{~K} \text { - montmorillonite }+2 \mathrm{SO}_{4}^{2-}+6 \mathrm{H}^{+}
\end{gathered}
$$

Calcite $+2 \mathrm{H}^{+} \rightleftharpoons \mathrm{Ca}^{2+}+\mathrm{CO}_{2}+\mathrm{H}_{2} \mathrm{O}$

Based on the results of the explorationwells in the volcanic rock of the TVG (MRSO 1969, 1970, 1971, 1973), the hydrothermal minerals in host volcanic rocks are rich in montmorillonite, chlorite, calcite, albite, adularia, illite, anhydrite, pyrite and chalcedony, which are very similar to the reaction products of acidic thermal water with andesites.

Meanwhile, laboratory experiments on andesitic chips from the TVG reacting with sulfuric acid of varying concentrations have been conducted (Fang et al. 2003). The result showed that plagioclase will be decomposed, but not pyroxene and hornblende. The mineral assemblages are the same as observed in the field at the TVG. According to the mineral assemblages of host rocks of the Type II hot springs, the reservoir of this type is suggested to be located in volcanic host rocks. Furthermore, the temperature of this type hot spring water is relatively low, which is about between $40^{\circ} \mathrm{C}$ and $50^{\circ} \mathrm{C}$, and the hydrogen and oxygen isotopic ratios are close to the local meteoric water line. For these lines of evidence, we can conclude that the Type II hot springs are located in a shallower reservoir.

In summary, this study suggests three source components involved in the origin of Type II hot springs. They are the meteoric water, magmatic fluids and volcanic host rocks, especially the plagioclase phenocrysts of andesite. A three-stage model is proposed to explain the geochemical characteristics of type II hot springs. First, meteoric water circulated to a shallow subsurface reservoir, and then heated by magmatic heat and reacted with magmatic fluids/ gases to generate acidic thermal water. Subsequently, this acidic thermal water resided in a reservoir of volcanic rock bodies, and then, neutralized by the plagioclase, precipitated the hydrothermal minerals, including montmorillonite, alunite, gypsum and kaolinite etc., and enriched in $\mathrm{Na}^{+}$and $\mathrm{HCO}_{3}-$ concentrations. Finally, this neutral hot spring was driven from shallower reservoir to the surface by thermal convection.

\subsubsection{Origin of Type III Thermal Water}

A Type III hot spring is $\mathrm{Cl}^{-}$-rich acidic thermal water and occurs in the Wuchishan Formation. Based on the stable isotopic ratios and their chemical characteristics of $\mathrm{Na}^{+}>$ $\left(\mathrm{Ca}^{2+}+\mathrm{Mg}^{2+}+\mathrm{K}^{+}\right)$and $\mathrm{Cl}^{-}>\left(\mathrm{HCO}_{3}{ }^{-}+\mathrm{SO}_{4}{ }^{2-}\right)$, two fluid components, the meteoric water and either seawater or formation water, are recognized to involve the origin of it.

Tapu (TP) and Jiatou (JT) thermal water are distributed near the coast in the northeast of the TVG. Their temperature and $\mathrm{pH}$ values change with the intrusion of a tidal current (Liu et al. 1984; Chen 2002). Thus, the seawater component is considered to play an important role in its origin. Nevertheless, Hsinpeitou (SPT) is located in the southwest of the belt adjacent to the Taipei Basin and is far away from the coast. The higher $\mathrm{Na}^{+}$and $\mathrm{Cl}^{-}$concentrations of the SPT thermal water cannot result from direct seawater involvement. However, it is most likely brine water (formation water), in which pore fluid may be from the Wuchishan Formation. Geothermal drilling data also supports the formation water from that Wuchishan Formation is involved in the origin of Hsinpeitou (SPT) thermal water (MRSO 1969).

As shown in Fig. 6b, the plot of $\mathrm{Cl}^{-}$vs. $\mathrm{Na}^{+}$shows that Type III thermal water occurred by the mixing of meteoric water and seawater or formation water. In addition, the hydrogen and oxygen isotopic ratios of JT and TP water samples fall in the mixing line of the meteoric water and seawater (Fig. 4). However, the SPT water sample is far from the meteoric water and seawater mixing line, and shows heavier oxygen isotopic ratio. It is close to the Gueizikeng area, where clay minerals in the Wuchishan Formation were mined several decades ago. According to this observation, 


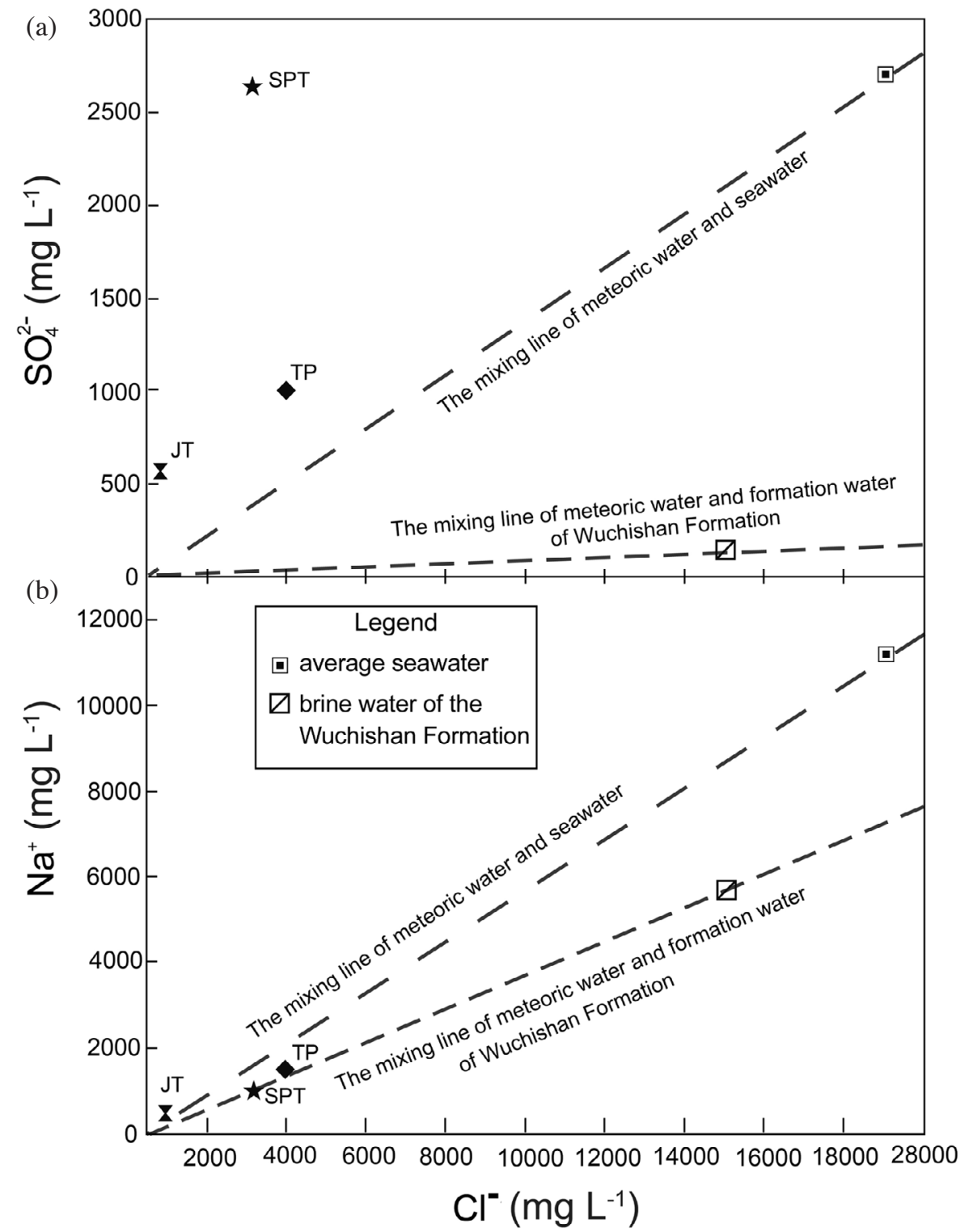

Fig. 6. (a) The $\mathrm{Cl}^{-}$vs. $\mathrm{SO}_{4}{ }^{2-}$ diagram shows that the origin of the TP, JT and SPT thermal water (Type III) is the mixing of meteoric water, volcanic fluids and average seawater (Goldberg et al. 1971) or formation water. (b) $\mathrm{A} \mathrm{Cl}^{-}$vs. $\mathrm{Na}^{+}$plot shows that the TP, JP and SPT thermal water are rich in $\mathrm{Na}^{+}$and $\mathrm{Cl}^{-}$concentrations .

the SPT thermal water may have been sourced from hot water reacting with clay minerals.

In Fig. 6a, the plot of $\mathrm{Cl}^{-}$vs. $\mathrm{SO}_{4}{ }^{2-}$ indicates that the Type III thermal water is not simply along the mixing lines of meteoric water and seawater or formation water of the Wuchishan Formation. Furthermore, the plot of stable isotopic ratio of hydrogen and oxygen, high temperature steam, sulfur dendritic crystals precipitated around the rim of fumaroles and helium isotopes (Yang et al. 2003) infer that the magmatic fluids have also involved in the origin of Type III thermal water (Fig. 4). However, higher sulfur isotopic ratio suggests that the influence of magmatic fluids does not really change the volcanic affinity of these samples. According to the sulfur and helium isotopic values of volcanic gas of the TVG (Ho 2001; Yang et al. 2003; Lee et al. 2008; Ohba, et al.2010) as well as the regional geology, we can conclude that the reservoir is located in the sedimentary terrane.

In summary, we propose that three components including the meteoric water, and formation water or seawater with relatively less magmatic fluids are involved in the origin of Type III thermal water. First, local meteoric water circulated into the subsurface reservoir, and was heated and reacted with magmatic fluids generating acidic thermal water. Since the reservoir is located in the shallower Wuchishan Formation, which is quartz-rich sedimentary rock, the thermal water was not able to be neutralized by host rocks. It maintained its acidic characteristics when it was driven to the surface by thermal convection. Here, this acidic thermal water mixed 
with different water bodies to change its composition. In the Tapu (TP) and Joatou (JT) areas, the thermal waters are generated by mixing with abundant seawater during uprising to the surface. Their geochemical characteristics, thus, display acidity, higher chlorine and sodium concentrations with sedimentary-origin sulfur isotopic ratios. For Hsinpeitou (SPT) thermal water, it is generated by mixing with formation water of the Wuchishan Formation to generate the acidity, higher chlorine and sodium concentrations with sedimentary-origin sulfur isotopic value. Furthermore, the SPT water may react with clay minerals of the Wuchishan Formation lately to shift oxygen isotopic value as shown in Fig. 4 (Savin and Epstein 1970; Lawrence and Taylor 1972; Jame and Baker 1976; Criss 1999; Hoefs 2004).

\section{CONCLUSION}

According to geochemical characteristics and field occurrences, three types of thermal water are distinguished for the TVG as shown in Fig. 7. The hydrothermal model to generate the thermal water is proposed as below.

(1) Type $\mathrm{I}$ is $\mathrm{SO}_{4}{ }^{2-}$ acidic thermal water as a result of the meteoric water being heated and reacted with magmatic fluids in the deep of Wuchishan Formation. Finally, the acidic thermal water is driven from reservoir to the surface by thermal convection, and also affected by evaporation during rising.

(2) Type II is a nearly neutral $\mathrm{HCO}_{3}{ }^{-}$hot spring, which is generated by meteoric water absorbing volcanic gases to generate acidic thermal water in shallow andesitic host rocks. Then, this acidic thermal water is neutralized with the plagioclase of two-pyroxene and two-pyroxene hornblende andesites to precipitate hydrothermal minerals including montmorillonite, alunite, gypsum, calcite and kaolinite etc.

(3) Type III is $\mathrm{Cl}^{-}$-rich acidic thermal water that is caused by the mixing of meteoric water and seawater or formation water with magmatic fluids, and heated by conducted heat from underneath magma in the reservoir of the shallower Wuchishan Formation. The sedimentary rock is a major factor that causes the high sulfur isotope in this type.

Acknowledgements The authors thank two reviewers and editor for comments, which help improve the focus of this paper. Additionally, the authors appreciate the assistance of Mr. R. W. Kou for the field samplings and partial IC and ICP-AES analyses, and the Y. G. Chen professor for H-O-S isotopic analyses. This research is indebted to Central Geological Survey of the MOEA for the financial support under the grants CGS-MOE-5226902000-04-95-01, CGS-MOE96-5226902000-01-01 and NSC 98-3114-M-002 -001.

\section{REFERENCES}

Belousov, A., M. Belousova, C. H. Chen, and G. F. Zellmer, 2010: Deposits, character and timing of recent eruptions and gravitational collapses in Tatun Volcanic Group, Northern Taiwan: Hazard-related issues. J. Vol-

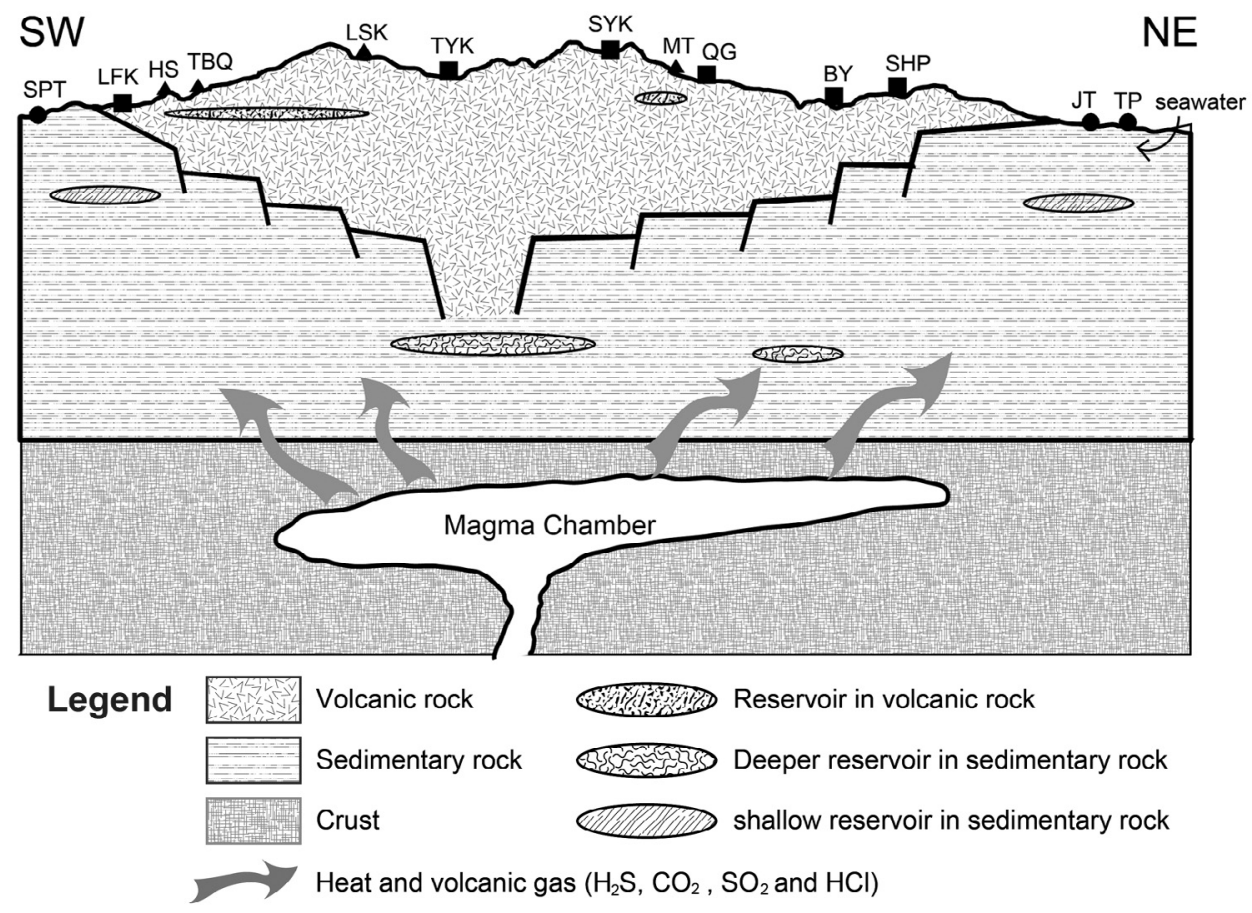

Fig. 7. A schematic model illustrates the characteristics and origins of hot springs from the TVG area. See text for further detailed discussion. 
canol. Geotherm. Res., 191, 205-221, doi: 10.1016/j. jvolgeores.2010.02.001. [Link]

Chen, C. H., 1975: Petrological and chemical study of volcanic rocks from Tatun Volcano Group. Proc. Geol. Soc. China, 18, 59-72.

Chen, C. H., 1989: The hot spring and geothermal in Taiwan. Ti-Chih, 9, 327-340. (in Chinese)

Chen, C. H. and Y. J. Wu, 1971: Volcanic geology of the Tatun geothermal area, northern Taiwan. Proc. Geol. Soc. China, 14, 5-20.

Chen, C. H. and H. Y. Yang, 1984: Minerals paragenesis in the hydrothermal alteration of andesites, as exemplified by a geothermal well in the Tatun volcanic area, northern Taiwan. Proc. Geol. Soc. China, 27, 68-85.

Chen, P. Y., 1963: Rhyolite pebbles in the white sandstone of the Wuchihshan Formation of Taiwan. Proc. Geol. Soc. China, 6, 34-40.

Chen, Y. L., 2002: Chemical Compositions of Hot Spring Waters in the Tatun Volcanic Area and Their Influence on Stream Waters. Ph.D. Thesis, National Tawian University, Taipei, Taiwn, ROC, 216 pp.

Cinzia, F., A. Aiuppa, R. Favara, S. Gurrieri, and M. Valenza, 2004: Geochemical monitoring of groundwaters (1998-2001) at Vesuvius volcano (Italy). J. Volcanol. Geotherm. Res., 133, 81-104, doi: 10.1016/S0377-02 73(03)00392-5. [Link]

Cohn, M. and H. C. Urey, 1938: Oxygen exchange reactions of organic compounds and water. J. Am. Chem. Soc., 60, 679-687, doi: 10.1021/ja01270a052. [Link]

Coleman, M. L., T. J. Shepherd, J. J. Durham, J. E. Rouse, and G. R. Moore, 1982: Reduction of water with zinc for hydrogen isotope analysis. Anal. Chem., 54, 993995, doi: 10.1021/ac00243a035. [Link]

Craig, H., 1963: The isotopic geochemistry of water and carbon in geothermal areas. In: Tongiorgi, E. (Ed.), Nuclear Geology in Geothermal Areas, Cons. Naz. Ric., Laboratorio Geologia Nuclear, Italy, 17-53.

Criss, R. E., 1999: Principles of Stable Isotope Distribution. Oxford University Press, New York, USA, 254 pp.

Ellis, A. J. and W. A. J. Mahon, 1964: Natural hydrothermal systems and experimental hot-water/rock interactions. Geochim. Cosmochim. Acta, 28, 1323-1357, doi: 10.1016/0016-7037(64)90132-2. [Link]

Epstein, S. and T. Mayeda, 1953: Variation of $\mathrm{O}^{18}$ content of waters from natural sources. Geochim. Cosmochim. Acta, 4, 213-224, doi: 10.1016/0016-7037(53)90051-9. [Link]

Fang, J. N., H. J. Lo, S. R. Song, S. H. Chung, Y. L. Chen, I. C. Lin, B. S. Yu, H. F. Chen, L. J. Li, and C. M. Liu, 2003: Hydrothermal alteration of andesite in acid solutions: Experimental study in $0.05 \mathrm{M} \mathrm{H}_{2} \mathrm{SO}_{4}$ solution at $110^{\circ}$ C. J. Chin. Chem. Soc., 50, 239-244.

Friedman, I., 1953: Deuterium content of natural waters and other substances. Geochim. Cosmochim. Acta, 4, 89-
103, doi: 10.1016/0016-7037(53)90066-0. [Link]

Gat, J. R. and W. Dansgaard, 1972: Stable isotope survey of the fresh water occurrences in Israel and the Northern Jordan Rift Valley. J. Hydrol., 16, 177-211, doi: 10.1016/0022-1694(72)90052-2. [Link]

Giggenbach, W. F., 1988: Geothermal solute equilibra. Derivation of Na-K-Mg-Ca geoindicators. Geochim. Cosmochim. Acta, 52, 2749-2765, doi: 10.1016/0016-70 37(88)90143-3. [Link]

Giggenbach, W. F. and R. B. Glover, 1975: The use of chemical indicators in the surveillance of volcanic activity affecting the Crater Lake on Mt. Ruapehu, New Zealand. Bull. Volcanol., 39, 70-81, doi: 10.1007/BF0 2596947. [Link]

Goldberg, E. D., W. Broeker, M. G. Gross, and K. K. Turekian, 1971: Marine Chemistry. Radioactivity in the Marine Environment, National Academy of Sciences, Washington, DC, 137-145.

Gonfiantini, R., 1986: Environmental isotopes in lake studies. In: Fritz, P. and J. C. Fontes (Eds.), Handbook of Environmental Isotope Geochemistry 2, Elsevier, New York, 133-168.

Henley, R. W. and A. J. Ellis, 1983: Geothermal systems ancient and modern: A geochemical review. Earth-Sci. Rev., 19, 1-50, doi: 10.1016/0012-8252(83)90075-2. [Link]

Ho, C. S., 1986: A synthesis of the geologic evolution of Taiwan. Tectonophysics, 125, 1-16, doi: 10.1016/004 0-1951(86)90004-1. [Link]

Ho, H. H., 2001: The volcanic gas sources of Tatun Volcano Group, Northern Taiwan. Master Thesis, National Tawian University, Taipei, Taiwan, ROC, 79 pp.

Hoefs, J., 2004: Stable Isotope Geochemistry. Springer Verlag, Berlin Heidelberg, New York, 244 pp.

Huang, C. S., 1998: Geologic map of Taipei (1 : 50000), sheet $4,2^{\text {nd }}$ edition, Central Geological Survey, MOEA, Taipei, Taiwan, ROC. (in Chinese)

James, A. T. and D. R. Baker, 1976: Oxygen isotope exchange between illite and water at $22^{\circ} \mathrm{C}$. Geochim. Cosmochim. Acta, 40, 235-239, doi: 10.1016/0016-7037 (76)90180-0. [Link]

Juang, W. S., 1993: Diversity and origin of Quaternary basaltic magma series in northern Taiwan. Bull. Natl. Museum Nat. Sci., 4, 125-165.

Juang, W. S. and J. C. Chen, 1989: Geochronology and geochemistry of volcanic rocks in northern Taiwan. Bull. Cent. Geol. Surv., 5, 31-66. (in Chinese)

Kempter, K. A. and G. L. Rowe, 2000: Leakage of active crater lake brine through the north flank at Rincón de la Vieja volcano, northwest Costa Rica, and implications for crater collapse. J. Volcanol. Geotherm. Res., 97, 143-159, doi: 10.1016/S0377-0273(99)00181-X. [Link]

Kendall, C. and T. B. Coplen, 1985: Multi-sample conver- 
sion of water to hydrogen by zinc for stable isotope determination. Anal.Chem., 57, 1437-1440, doi: 10.1021/ ac00284a058. [Link]

Konstantinou, K. I., C. H. Lin, and W. T. Liang, 2007: Seismicity characteristics of a potentially active Quaternary volcano: The Tatun Volcano Group, northern Taiwan. J. Volcanol. Geotherm. Res., 160, 300-318, doi: 10.1016/j.jvolgeores.2006.09.009. [Link]

Kühn, M., 2004: Reactive Flow Modeling of Hydrothermal Systems. Springer Verlag, Berlin Heidelberg, New York, $261 \mathrm{pp}$.

Lai, Y. M., Y. J. Lin, S. R. Song, Y. W. Tsai, Y. C. Hsieh, and W. Lo, 2010: Topography and volcanology of the Huangtsuishan Volcano Subgroup, northern Taiwan. Terr. Atmos. Ocean. Sci., 21, 599-609, doi: 10.3319/ TAO.2010.02.22.04(TH). [Link]

Lan, T. F., T. F. Yang, H. F. Lee, Y. G. Chen, C. H. Chen, S. R. Song, and S. Tsao, 2007: Compositions and flux of soil gas in Liu-Huang-Ku hydrothermal area, northern Taiwan. J. Volcanol. Geotherm. Res., 165, 32-45, doi: 10.1016/j.jvolgeores.2007.04.015. [Link]

Lawrence, J. R. and H. P. Taylor, 1972: Hydrogen and oxygen isotope systematics in weathering profiles. Geochim. Cosmochim. Acta, 36, 1377-1393, doi: 10.1016/ 0016-7037(72)90068-3. [Link]

Lee, H. F., T. F. Yang, T. F. Lan, S. R. Song, and S. Tsao, 2005: Fumarolic gas composition of the Tatun Volcano Group, northern Taiwan. Terr. Atmos. Ocean. Sci., 16, 843-864.

Lee, H. F., T. F. Yang, T. F. Lan, C. H. Chen, S. R. Song, and S. Tsao, 2008: Temporal variations of gas compositions of fumaroles in the Tatun Volcano Group, northern Taiwan. J. Volcanol. Geotherm. Res., 178, 642-635, doi: 10.1016/j.jvolgeores.2008.06.005. [Link]

Lin, C. H., K. I. Konstantinou, W. T. Liang, H. C. Pu, Y. M. Lin, S. H. You, and Y. P. Huang, 2005: Preliminary analysis of volcanoseismic signals recorded at the Tatun volcano group, northern Taiwan. Geophys. Res. Lett., 32, L10313, doi: 10.1029/2005GL022861. [Link]

Lin, C. H., K. I. Konstantinou, and H.C. Pu, 2007: Volcanoseismic signals in the Tatun volcanic area. Bull. Natl. Parks, 17, 87-97. (in Chinese)

Liu, K. K., C. H. Chen, Y. N. Shieh, and S. C. Chiang, 1984: Hydrogen and oxygen isotopic compositions of meteoric waters from the Tatun Shan area, northern Taiwan. Bull. Inst. Earth Sci., Academia Sinica, 4, 159-175. (in Chinese)

López, D. L., J. Bundschuh, G. J. Soto, J. F. Fernández, and G. E. Alvarado, 2006: Chemical evolution of thermal springs at Arenal Volcano, Costa Rica: Effect of volcanic activity, precipitation, seismic activity, and Earth tides. J. Volcanol. Geotherm. Res., 157, 166-181, doi: 10.1016/j.jvolgeores.2006.03.049. [Link]
Marini, L., M. V.Zuccolini, and G. Saldi, 2003: The bimodal $\mathrm{pH}$ distribution of volcanic lake waters. J. Volcanol. Geotherm. Res., 121, 83-98, doi: 10.1016/S03770273(02)00413-4. [Link]

Martin-Del Pozzo, A.L., F. Aceves, R. Espinasa, A. Aguayo, S. Inguaggiato, P. Morales, and E. Cienfuegos, 2002: Influence of volcanic activity on spring water chemistry at Popocatepetl Volcano, Mexico. Chem. Geol., 190, 207-229, doi: 10.1016/S0009-2541(02)00117-1. [Link]

McNutt, S. R. and R. J. Beavan, 1981: Volcanic earthquakes at Pavlof volcano correlated with the solid earth tide. Nature, 294, 615-618, doi: 10.1038/294615a0. [Link]

MRSO, 1969: The geothermal exploration of the Tatun Volcano Group (I). MRSO Report, 90, 63 pp. (in Chinese)

MRSO, 1970: The geothermal exploration of the Tatun Volcano Group (II). MRSO Report, 102, 86 pp. (in Chinese)

MRSO, 1971: The geothermal exploration of the Tatun Volcano Group (III). MRSO Report, 111, 48 pp. (in Chinese)

MRSO, 1973: The Report on Geothermal Exploration of TVG, IV. Mining Research and Service Organization, 78 pp. (in Chinese)

Muir, I. J. and H. W. Nesbitt, 1992: Controls on differential leaching of calcium and aluminum from labradorite in dilute electrolyte solutions. Geochim. Cosmochim. Acta, 56, 3979-3985, doi: 10.1016/0016-7037(92)900 11-7. [Link]

Neuberg, J., 2000: External modulation of volcanic activity. Geophys. J. Int., 142, 232-240, doi: 10.1046/j.1365-24 6x.2000.00161.x. [Link]

Nicholson, K., 1993: Geothermal Fluids-Chemistry and Exploration Techniques. Springer Verlag, Berlin, New York, $263 \mathrm{pp}$.

Nogami, K. and M. Yoshida, 1995: Leaching rates of rockforming components through acidic alteration. $\mathrm{J}$. Volcanol. Geotherm. Res., 65, 41-49, doi: 10.1016/0377-0 273(95)93834-P. [Link]

Ohba, T., T. Sawa, N. Taira, T. F. Yang, H. F. Lee, T. F. Lan, M. Ohwada, N. Morikawa, and K. Kazahaya, 2010: Magmatic fluids of Tatun volcanic group, Taiwan. Appl. Geochem., 25, 513-523, doi: 10.1016/j. apgeochem.2010.01.009. [Link]

Okamoto, Y., 1918: On The Hokutolite (Japanese). Nat. History Soc. Formosa Trans., 8, p 26.

Piper, A. M., 1944: A graphic procedure in the geochemical interpretation of water-analysis. Am. Geophys. Union, Trans., 25, 914-923.

Rydelek, P. A., P. M. Davis, and R. Y. Koyanagi, 1988: Tidal triggering of earthquake swarms at Kilauea volcano, Hawaii. J. Geophys. Res., 93, 4401-4411, doi: 10.1029/JB093iB05p04401. [Link] 
Savin, S. M. and S. Epstein, 1970: The oxygen and hydrogen isotope geochemistry of clay minerals. Geochim. Cosmochim. Acta, 34, 25-42, doi: 10.1016/0016-7037 (70)90149-3. [Link]

Seno, T., 1977: The instantaneous rotation vector of the Philippine Sea plate relative to the Eurasian plate. Tectonophysics, 42, 209-226, doi: 10.1016/0040-1951(77) 90168-8. [Link]

Seyfried, W. E. and J. L. Bischoff, 1981: Experimental seawater-basalt interaction at $300^{\circ} \mathrm{C}, 500$ bars, chemical exchange, secondary mineral formation and implications for the transport of heavy metals. Geochim. Cosmochim. Acta, 45, 135-147, doi: 10.1016/0016-70 37(81)90157-5. [Link]

Shieh, Y. N., F.P. Cherng, and T.C. Hoering, 1983: Oxygen and hydrogen isotope studies of meteoric and thermal waters in Taiwan. Mem. Geol. Soc. China, 5, 127-140.

Song, S. R., T. F. Yang, Y. H. Yeh, S. Tsao, and H. J. Lo, 2000a: The Tatun volcano group is active or extinct? $J$. Geol. Soc. China, 43, 521-534.

Song, S. R., S. Tsao, and H. J. Lo, 2000b: Characteristics of the Tatun volcanic eruptions, north Taiwan: Implications for a cauldron formation and volcanic evolution. J. Geol. Soc. China, 43, 361-378.

Suppe, J., 1984: Kinematics of arc-continent collision, flipping of subduction, and back-arc spreading near Taiwan. Mem. Geol. Soc. China, 6, 21-34.

Szakács, A., 1994: Redefining active volcanoes: A discussion. Bull. Volcanol., 56, 321-325, doi: 10.1007/BF00 326458. [Link]

Taylor, D. and D. E. Hayes, 1980: The tectonic evolution of the South China Sea Basin. In: Hayes, D. E. (Ed.), The Tectonic and Geologic Evolution of Southeast Asian Seas and Island. Geophysical Monograph Series 23, American Geophysical Union, 89-104.

Teng, L. S., 1996: Extensional collapse of the northern Taiwan mountain belt. Geology, 24, 949-952, doi: 10.11 30/0091-7613(1996)024<0949:ECOTNT>2.3.CO;2. [Link]

Teng, L. S., C. H. Chen, T. K. Liu, W. S. Juang, and J. C. Chen, 1992: Plate kinematic model for late Cenozoic arc magmatism in northern Taiwan. Geol. Soc. China, 35, 1-18.

Todd, D. K., 1980: Groundwater Hydrology. $2^{\text {nd }}$ Ed., John Wiley and Sons, New York, 556 pp.

Tsai, Y. B., 1978: Plate subduction and the Plio-Pleistocene orogeny in Taiwan. Petrol. Geol. Taiwan, 15, 1-10.

Tsai, Y. B., Z. S. Liaw, T. Q. Lee, M. T. Lin, and Y. H. Yeh, 1981: Seismological evidence of an active plate boundary in the Taiwan area. Mem. Geol. Soc. China, 4, 143-154.

Tsai, Y. W., S. R. Song, H. F. Chen, S. F. Li, C. H. Lo, W. Lo, and S. Tsao, 2010: Volcanic stratigraphy and potential hazards of the Chihsingshan Volcano Sub- group in the Tatun Volcano Group, northern Taiwan. Terr. Atmos. Ocean. Sci., 21, 587-598, doi: 10.3319/ TAO.2010.02.22.03(TH). [Link]

Tsao, S., 1994: K-Ar age determination of volcanic rocks from the Tatun Volcano Group. Bull. Cent. Geol. Surv., 9, 137-154. (in Chinese)

Varekamp, J. C., G. B. Pasternack, and G. L. Rowe Jr., 2000: Volcanic lake systematics II. Chemical constraints. $J$. Volcanol. Geotherm. Res., 97, 161-179, doi: 10.1016/ S0377-0273(99)00182-1. [Link]

Wang, C. H., 1991: The stable isotopic compositions on geothermal waters of the Tatun volcanic area, Taiwan. Tech. Report, Inst. Earth Sci., Academia Sinica, 36 pp. (in Chinese).

Wang, K. L., S.L.Chung, C.H.Chen, R. Shinjo, T.F. Yang, and C. H. Chen, 1999: Post-collisional magmatism around northern Taiwan and its relation with opening of the Okinawa Trough. Tectonophysics, 308, 363-376, doi: 10.1016/S0040-1951(99)00111-0. [Link]

Wang, K. L., S. L. Chung, C. H. Chen, and C. H. Chen, 2002: Geochemical constraints on the petrogenesis of high$\mathrm{Mg}$ basaltic andesites from the northern Taiwan volcanic zone. Chem. Geol., 182, 513-528, doi: 10.1016/ S0009-2541(01)00338-2. [Link]

Wang, K. L., S. L. Chung, S. Y. O’Reilly, S. S. Sun, R. Shinjo, and C. H. Chen, 2004: Geochemical constraints for the genesis of post-collisional magmatism and the geodynamic evolution of the northern Taiwan region. $J$. Petrol., 45, 975-1011, doi: 10.1093/petrology/egh001. [Link]

Wang, W. H. and C. H. Chen, 1990: The volcanology and fission track age dating of pyroclastic deposits in TVG. Acta Geol. Taiwan., 28, 1-30.

Williams, S. N., R. E. Stoiber, N. Garcia P., A. Londoño C., J. B. Gemmell, D. R. Lowe, and C. B. Connor, 1986: Eruption of the Nevado del Ruiz Volcano, Colombia, on 13 November 1985: Gas flux and fluid geochemistry. Science, 233, 964-967, doi: 10.1126/science.233. 4767.964. [Link]

Williams-Jones, G., J. Stix, M. Heiligmann, J. Barquero, E. Fernandez, and E. D. Gonzalez, 2001: A model of degassing and seismicity at Arenal Volcano, Costa Rica. J. Volcanol. Geotherm. Res., 108, 121-139, doi: 10.1016/S0377-0273(00)00281-X. [Link]

Wu, F. T., 1967: Petrographic study of oil sands of the Mushan and the Wuchihshan Formation in the vicinity of Miaoli, Taiwan. Petrol. Geol. Taiwan, 5, 45-61.

Wu, F. T., 1978: Recent tectonics of Taiwan. J. Phys. Earth, 26, 265-299.

Yang, T. F., Y. Sano, and S. R. Song, 1999: ${ }^{3} \mathrm{He} /{ }^{4} \mathrm{He}$ ratio of fumaroles and bubbling gases of hot spring in Tatun Volcano Group, North Taiwan. Nuovo Cimento, 22C, 281-286.

Yang, T. F., H. H. Ho, P. S. Hsieh, N. J. Liu, Y. G. Chen, 
and C. H. Chen, 2003: Sources of fumarolic gases from Tatun Volcano Group, North Taiwan. J. Natl. Park, 13, 127-156. (in Chinese)

Yanagisawa, F. and H. Sakai, 1983: Thermal decomposition of barium sulfate-vanadium pentoxide-silica glass mixtures for preparation of sulfur dioxide in sulfur isotope ratio measurements. Anal. Chem., 55, 985-987, doi: 10.1021/ac00257a046. [Link]

Yen, T. P., 1978: Geologic relations between northern Taiwan and southern Ryukyu islands. Acta Oceanogr. Taiwan., 8, 1-21.

Yu, S. B., H. Y. Chen, and L. C. Kuo, 1997: Velocity field of GPS stations in the Taiwan area. Tectonophysics, 274, 41-59, doi: 10.1016/S0040-1951(96)00297-1. [Link] 